\title{
PENAMPILAN TINGKAH LAKU SEKSUAL SAPI PEJANTAN LIMOUSIN DAN SIMMENTAL DI BALAI INSEMINASI BUATAN LEMBANG
}

\author{
Achmad F.Sam, E.Pudjihastuti , M. J. Hendrik , L.Ngangi* \\ dan IGP.N.Raka**
}

\author{
Fakultas Peternakan Universitas Sam Ratulangi Manado, 95115 \\ ***Baiai Inseminasi Buatan Lembang, Bandung 40391
}

\begin{abstract}
ABSTRAK
Untuk memperoleh pejantan IB unggul tidak lepas dari upaya melakukan manajemen pemeliharaan yang baik. Manajemen pemeliharaan pejantan antara lain melaksanakan pemeriksaan fisik dan tingkah laku seksual. Berdasarkan hal tersebut maka telah dilakukan penelitian untuk mengamati penampilan tingkah laku seksual sapi pejantan Limousin dan Simmental di Balai Inseminasi Buatan Lembang Bandung.Tujuan dari penelitian ini untuk melihat gambaran karakteristik tingkah laku seksual sapi pejantan Limousin dan Simmental yang ada di Balai Inseminasi Buatan Lembang. Materi yang digunakan dalam penelitian ini yaitu 80 ekor sapi pejantan yang terdiri dari 40 ekor jenis Limousin dan 40 ekor jenis Simmental dengan kisaran umur 6-9 tahun. Pengambilan data dilakukan dengan metode observasi teknik focal animal sampling.Pengamatan tingkah laku seksual dilaksanakan selama 10 hari dan berlangsung setiap pagi hari mulai pukul 07.00 -11.00 WIB.Pengambilan data dimulai sejak sapi pejantan digabung dengan teaser. Berdasarkan hasil penelitian terhadap tingkah laku seksual maka dapat disimpulkan bahwa sapi pejantan Limousin membutuhkan lama waktu lebih singkat (2,22 detik) untuk mulai bercumbu dan sapi Simmental (2,77 detik), mulai flehmen (222 detik) sapi Simmental (239 detik) , dan untuk lama waktu yang dibutuhkan untuk pertama kali menaiki sapi Limousin (214,37 detik) sapi Simmental $(302,45)$. Sedangkan untuk frekuensi flehmen sapi pejantan Limousin dan Simmental sama (satu kali).
\end{abstract}

Kata kunci :Limousin, simmental,perilaku seksual,

*Korespondensi (Corresponding Author)

Email: lentjingangi@gmail.com
ABSTRACT

SEXUAL BEHAVIOR OF LIMOUSIN AND SIMMENTAL BULL BREEDSAT THE LEMBANG ARTIFICIAL INSEMINATION CENTER. In order to provide the prominent bulls, the management process of animal selection was required for animal replacement stock. Animal selection was including the inspection of animal physical and sexual behavior. Based on this criterion, study was conducted to observe the sexual behavior of Limousin and Simmental breed bulls at the artificial insemination center in Lembang, Bandung. The objective of this study was to evaluate the characteristic of sexual behavior of the Limousin and Simmental breed bulls. The amount of 80 bulls consisted of 40 Limousin and 40 Simmental bulls at the age of 6 to 9 years old were used in this study. Data collections were conducted by focal animal sampling. Sexual behavior was observed during ten days at the time from 07.00 to 11.00 West Indonesian Time. Data collection were started at the period of bull was introduced into teaser.Based on t-test on sexual behavior of Limousin and Simmental bulls, the results showed that (1) The time need for courtship with teaser of Limousin bull was significantly shorter $(\mathrm{P}<0,01)$ compared with Simmental bull; (2) Time period use for the first time to start flehmen of Limousin bull was shorter significantly $(\mathrm{P}<0,01) \quad$ compared with Simmental bull; (3) Flehmen frequency of Limousin and Simmental was non significantly.Based on the observation of sexual behavior, the Limousin bull need time of the 2,22 seconds to start courthip with teaser, while Simmental bull need time of 2,77 seconds to start courtship with teaser. The Limousin bull need time of 222 seconds to 
start flehmen, while Simmental bull need time of 239 seconds to start flehmen. The time periods used for the first time to mount teaser by Limousin bull were 214,87 seconds, while those by Simmental bull were 302,02 seconds. The flehmen frequency of Limousin dan Simmental bulls was similar of only one time during sexual behavior.

Key Words :Limousin, Simmental, Sexual behavior, Lembang Artificial Insemination Center

\section{PENDAHULUAN}

Pejantan IB adalah pejantan unggul yang memenuhi syarat teknis reproduktif untuk dapat ditampung semennya dan diproses menjadi semen beku.Pejantan tersebut dapat berasal dari impor maupun lokal.Kualitas semen beku yang baik hanya akan diperoleh dari pejantan-pejantan unggul yang memenuhi syarat tertentu. Salah satu syarat yang harus dimiliki oleh pejantan unggul sebagai sumber semen beku yaitu syarat reproduksi yang mencakupHafez (2002)(1) Libido tinggi;(2)Serving ability(kesanggupan melayani/mengawini) baik; (3)Serving capability (kemampuan melayani /mengawini) baik;(4)Warna semen putih susu kekuningan.

Libido atau daya keinginan untuk kawin dimanifestasikan dalam bentuk tingkah laku seksual (sexual behavior), yang terjadi sebagai respon dari ternak jantan karena adanya stimulans.Tingkah laku seksual muncul dan dapat diamati pada saat pra kopulasi, kopulasi dan pasca kopulasi.Pola kopulasi pada ternak sapi meliputi sex arousal, courtship (sexual display) atau percumbuan, ereksi, menaiki (mounting) yang belangsung pada saat pre kopulasi dan ejakulasi pada saat kopulasi. Dalam proses percumbuan hewan jantan akan menunjukkan respons tingkah laku mendekati betina atau teaser, mencium organ genetalia bagian luar, kemudian diikuti dengan mencoba menaiki tanpa diiringi dengan kopulasi.

Libido atau daya keinginan untuk kawin dimanifestasikan dalam bentuk tingkah laku seksual (sexual behavior), yang terjadi sebagai respon dari ternak jantan karena adanya stimulans. Tingkah laku seksual muncul dan dapat diamati pada saat pra kopulasi, kopulasi dan pasca kopulasi.Pola kopulasi pada ternak sapi meliputi sex arousal, courtship (sexual display) atau percumbuan, ereksi, menaiki (mounting) yang belangsung pada saat pre kopulasi dan ejakulasi pada saat kopulasi.Campbell dkk (2004) Dalam proses percumbuan hewan jantan akan menunjukkan respons tingkah laku mendekati betina atau teaser, mencium organ genetalia bagian luar, kemudian diikuti dengan mencoba menaiki tanpa diiringi dengan kopulasi.

Tingkah laku seksual harus benarbenar diperhatikan pada waktu penampungan, sensasi-sensasi visual, olfaktoris dan perabaan semuanya membantu daya tarik seksual dan mempermudah pelaksanaan kopulasi atau penampungan semen karena stimulasistimulasi atau rangsangan prekoital dapat meningkatkan volume ejakulat, konsentrasi sperma dan prosentase sperma yang hidup (Toelihere, 1999). Persiapan seksual sebelum penampungan semen dapat meningkatkan jumlah sperma hingga 100 persen (Hafez , 2002).

Kelanjutan perkembangan peternakan sangat ditentukan dan tergantung pada salah faktor kesiapan dari BIB Lembang dalam 
memproduksi semen beku yang berkualitas.Agar semen beku dapat terjamin ketersediaannya secara kuantitas dan kualitas maka tersedianya sapi-sapi pejantan unggul yang memenuhi syarat reproduktif dan memiliki tampilan prestasi reproduksi yang baik sangatlah diperlukan. Untuk memenuhi hal tersebut maka perlu ditunjang oleh faktorfaktor penentu yang termasuk diantaranya yaitu penampilan tingkah laku seksual. Pemahaman akan tingkah laku seksual dapat memberikan informasi mengenai apa saja yang dibutuhkan sapi dalam kelanjutan reproduksinyaAnonim (2004). Informasi ini penting bagi kita semua terutama pihak Balai Inseminasi Buatan (BIB) Lembang dalam upaya mengkondisikan dan merencanakan manajemen yang sesuai, agar kedepannya sapi pejantan Limousin dan Simmental bisa menghasilkan produksi semen yang optimal sesuai dengan potensi genetiknya. Berdasarkan kerangka pemikiran yang tercantum diatas, maka telah dilaksanakan penelitian yang dengan judul "Penampilan Tingkah Laku Seksual Sapi Pejantan Limousin dan Simmental di Balai Inseminasi Buatan Lembang" yang bertujuan ntuk mengetahui pengaruh tingkah laku seksual terhadap kualitas libido dari sapi Limousin dan Simmental yang ada di BIB Lembang.

\section{METODE PENELITIAN}

Penelitian ini dilaksanakan di Balai Inseminasi Buatan Lembang Bandung provinsi Jawa Barat, berlangsung selama sepuluh hari, mulai tanggal 7 sampai dengan 17 November
2016. Pengambilan data dilakukan setiap hari kerja dimulai pada pukul $07.00-11.00$ WIB.Ternak yang digunakan dalam penelitian ini adalah sapi pejantan Limousin dan Simmental berumur sekitar 6-9 tahun sebanyak 80 ekor milik dari Balai Inseminasi Buatan Lembang. Pengambilan data dilakukan dengan metode observasi teknik focal animal sampling yang mengharuskan pengamatan langsung dilokasi penelitian dimana materi penelitian berada.Model pengamatan ini dilakukan dengan fokus pada satu obyek penelitian dengan prinsip metode "siapa melakukan apa terhadap siapa" (Yamin dkk, 2014).Pengamatan tingkah laku seksual pejantan berlangsung pada saat digabung dengan teaser (ternak penggoda) atau dummy cow atau pada saat akan diadakan penampungan semen, yang berlangsung setiap hari kerja dimulai pukul 07.00-11.00. Pengukuran suhu udara dilakukan dengan menggunakan thermometer pada setiap hari disaat penampungan semen berlangsung. Untuk meningkatkan libido dari tiap sapi pejantan, maka dilakukan falsemounting (pengekangan) sebanyak tiga kali kemudian dilanjutkan dengan mounting, ejakulasi, sampai proses penampungan selesai. Tingkah laku seksual yang diamati adalah tingkah laku yang muncul pada saat prekopulatorik.

Data diolah secara statistik sederhana yaitu standar deviasi dan koefisien keragaman dan disajikan dalam bentuk tabel, grafik dan gambar.Untuk mengetahui penampilan seksual dari sapi pejantan Limousin dan Simmental dilanjutkan dengan uji-t. 


\section{Variabel Penelitian}

Waktu pertama mencumbu teaser :memulai mencumbu atau mencium teaser sejak pertama kali didekatkan dengan ternak pemancing.

Waktu timbul flehmen :flehmen yaitu kelakuan khas pejantan apabila terangsang dengan memperlihatkan tanda mengangkat bibir dan kepala ke atas.

Frekuensi atau jumlah flehmen: Observasi dilakukan dengan melihat berapa kali pejantan memperlihatkan tanda terangsang berupa flehmen.

Waktu pertama kali menaiki teaser:Waktu yang dibutuhkan pejantan untuk menaiki teaser untuk pertama kali, tetapi belum melakukan kopulasi dan ejakulasi.

\section{HASIL DAN PEMBAHASAN}

\section{Waktu pertama mencumbu teaser}

Bercumbu salah satu fungsi penting sebagai komunikasi secara kimiawi melalui indera penciuman. Proses bercumbu dapat digambarkan sebagai upaya dari pejantan untuk merayu agar mau menerima pejantan dan bersedia dikawini. Nilai rerata lama waktu yang dibutuhkan sapi pejantan Limousin dan Simmental untuk mulai mencumbu teaser dapat dilihat pada Tabel 1.Hasil pengamatan dilapangan menunjukkan bahwa sapi pejantan Limousin dan Simmental mempunyai keinginan kawin (libido) yang baikAbror. 2010.Hal ini dibuktikan dengan adanya respons mendekati teaser dan mulai melakukan upaya bercumbu dalam waktu yang relatif singkat. Terdapat selisih waktu 0,55 detik dalam perolehan angka lama waktu yang dibutuhkan untuk memulai bercumbu. Sapi Limousin memiliki waktu lebih cepat 0,55 detik dalam hal mulai mencumbu teaser dibanding sapi pejantan Simmental.Perilaku seksual bercumbu yang nampak dan terinventarisir pada pejantan Limousin dan Simental selama penelitian yaitu menggesekgesekkan tubuhnya ke tubuh teaser, mencium alat kelamin bagian luar (Wotzicka dkk, 1991, Toelihere.1999., Campbell dkk, 2004), dan mengeluarkan suara leguhan (bellowing) (Abror, 2010).Lebih lanjut Toelihere (1999) menyatakan pola-pola motorik kopulasi bersifat sterotip dan pada garis besarnya tidak dirobah oleh pengalaman.Tingkah laku seksual termasuk bentuk tingkah laku yang bersifat naluri atau insting.Bentuk tingkah laku ini tidak bisa dimodifikasi tetap konstan sama untuk semua anggota individu (spesies) tidak diajarkan atau "imprinting" (Wodzicka dkk, 1991).

Tabel 1. Lama waktu yang dibutuhkan sapi pejantan untuk mulai mencumbu teaser

\begin{tabular}{llll}
\hline Bangsa sapi & Rerata (detik) & Sd & KK (\%) \\
\hline Limousin & 2,22 & 0,69 & 31,08 \\
\hline Simmental & 2,77 & 0,88 & 38,76 \\
\hline
\end{tabular}


Hasil analisis dengan menggunakan uji-t lama waktu yang dibutuhkan untuk mulai mencumbu teaser sapi pejantan Limousin memberi pengaruh sangat nyata $(\mathrm{P}<0,01)$ dibanding dengan sapi Simmental. Hasil ini menunjukkan bahwa sapi Limousin membutuhkan waktu lebih singkat untuk mulai bercumbu dengan teaser dibanding dengan sapi pejantan Simmental.

\section{Waktu Timbul Flehmen}

Nilai rerata waktu yang dibutuhkan sapi pejantan limousin dan Simmental di BIB Lembang untuk mulai flehmen tertera pada Tabel 2. Flehmen terjadi dengan cara kepaladiangkat dan dijulurkan,bibir atas dilipat keatas,mulut sedikit dibuka Kejadian flehmen normalnya mengggambarkan bagaimana cara sapi jantan mendeteksi apakah betina atau teaser dalam keadaan estrus.Sapi Limousin dan Simmental yang ada di BIB Lembang menampakkan respons flehmen dengan rerata lama waktu yang dibutuhkan untuk mulai flehmen masing-masing 222 detik dan 239 detik.Bangsa sapi pejantanLimousin menampakkan tingkah laku flehmen lebih cepat 17 detik dibanding sapi pejantan Simmental.Hal ini dapat diartikan sapi pejantan Limousin membutuhkan waktu lebih singkat untuk mulai menampakkan flehmen dibanding sapi pejantan Simmental. Hasil analisis dengan menggunakan uji-t lama waktu yang dibutuhkan untuk flehmen pertama kali sapi pejantan Limousin berbeda sangat nyata $(\mathrm{P}<0,01)$ dibanding dengan sapi pejantan Simmental. Bervariasinya waktu flehmen pada setiap individual sapi Limmousin maupun Simmental menggambarkan adanya perbedaan respons individu dalam menanggapi stimulans dilingkungannya Lopez (1999).Persentase sapi pejantan Limousin dan Simmental yang menunjukkan tingkah laku flehmen yang diperoleh selama penelitian sepuluh hari yaitu dari 40 ekor sapi pejantan Limousin yang menjadi materi penelitian, yang menampakkan tingkah laku flehmen 10 ekor (25\%) dan yang tidak menampakkan flehmen 30 ekor (75\%). Hal yang sama ditunjukkan oleh sapi pejantan Simmental dimana persentase angka capaian untuk yang menunjukkan flehmen 10 ekor (25\%) dan yang tidak menunjukkan flehmen sebanyak 30 ekor (75\%) (Gambar 1a,1b). Flehmen terjadi dengan cara kepala diangkat dan dijulurkan, bibir atas dilipat keatas, mulut sedikit dibuka. Kejadian flehmen normalnya mengggambarkan bagaimana cara sapi jantan mendeteksi apakah betina atau teaser dalam keadaan estrus. Sapi Limousin dan Simmental yang ada di BIB Lembang menampakkan respons flehmen dengan rerata lama waktu yang dibutuhkan untuk mulai flehmen masingmasing 222 detik dan 239 detik.Bangsa sapi pejantanLimousin menampakkan tingkah laku flehmen lebih cepat 17 detik dibanding sapi pejantan Simmental.

Tabel 2. Lama waktu yang dibutuhkan sapi pejantan untuk mulai flehmen

\begin{tabular}{llll}
\hline Bangsa sapi & Rerata (detik) & Sd & KK (\%) \\
\hline Limousin & 222 & 56,92 & 25,54 \\
Simmental & 239 & 86,64 & 36 \\
& & & \\
\hline
\end{tabular}




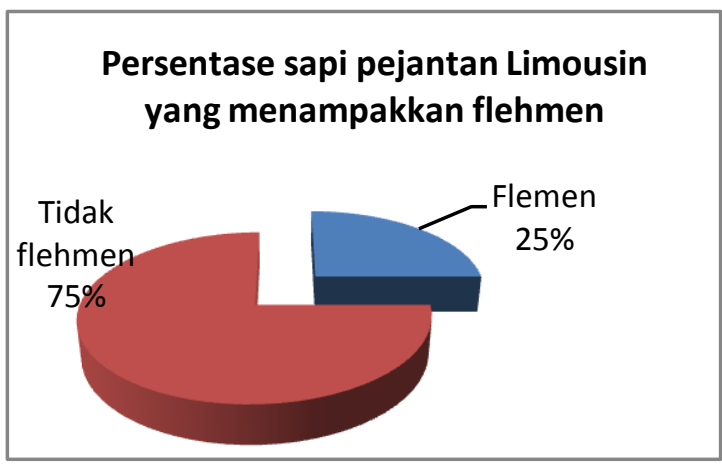

Gambar 1a.Persentase sapi pejantan Limousin

Hal ini dapat diartikan sapi pejantan Limousin membutuhkan waktu lebih singkat untuk mulai menampakkan flehmen dibanding sapi pejantan Simmental.Hasil analisis dengan menggunakan uji-t lama waktu yang dibutuhkan untuk flehmen pertama kali sapi pejantan Limousin berbeda sangat nyata $(\mathrm{P}<0,01)$ dibanding dengan sapi pejantan

Simmental. Bervariasinya waktu flehmen pada setiap individual sapi Limmousin maupun Simmental menggambarkan adanya perbedaan respons individu dalam menanggapi stimulans dilingkungannya.Persentase sapi pejantan Limousin dan Simmental yang menunjukkan tingkah laku flehmen yang diperoleh selama penelitian sepuluh hari yaitu dari 40 ekor sapi pejantan Limousin yang menjadi materi penelitian, yang menampakkan tingkah laku flehmen 10 ekor (25\%) dan yang tidak menampakkan flehmen 30 ekor (75\%). Hal yang sama ditunjukkan oleh sapi pejantan Simmental dimana persentase angka capaian untuk yang menunjukkan flehmen 10 ekor $(25 \%)$ dan yang tidak menunjukkan flehmen sebanyak 30 ekor $\quad(75 \%) \quad$ (Gambar 1).Tingginya persentase $(75 \%)$ sapi pejantan Limousin maupun Simmental yang tidak

\section{Persentase sapi pejantan Simmental yang menampakkan flehmen}

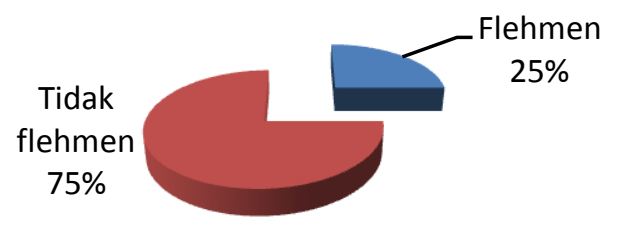

Gambar 1b. Persentase sapi pejantan Simmental menampakkan tingkah laku flehmen, diduga karena teaseryang berfungsi sebagai pengusik atau penggoda yang digunakan di BIB Lembang berjenis kelamin jantan.Fenomena ini terjadi karena sapi pejantan Limousin maupun Simmental tidak berespons menunjukkan tingkah laku flehmen karena tidak adanya stimulans yang berupa bau feromon dan cairan yang biasanya dikeluarkan oleh sapi betina yang sedang estrus.Respons flehmen oleh pejantan merupakan suatu upaya dari pejantan untuk mendeteksi ada tidaknya betina estrus yang terjadi setelah pejantan membaui urin teaser.Respons sapi muncul karena adanya stimulans yang diterima lewat indera penglihatan, penciuman, perabaan dan pendengaran (Toelihere 1999, Hafez 2002 dan Feradis, 2010). Sankar et al (2004) melaporkan bahwa sapi pejantan akan berespons tinggi menampakan flehmen apabila digabung dengan betina estrus yang mengeluarkan cairan dan bau feromon.

\section{Frekuensi Flehmen}

Data rerata pengulangan atau frekuensi flehmen oleh pejantan Limousin dan Simemental tertera pada tabel 3. 
Tabel 3. Rerata frekuensi flehmen sapi pejantan Limousin dan Simmental

\begin{tabular}{|c|c|}
\hline Limousin & Simmental \\
\hline $\begin{array}{c}\text { Banyaknya } \\
\text { Flehmen (kali) }\end{array}$ & $\begin{array}{c}\text { Banyaknya } \\
\text { Flehmen (kali) }\end{array}$ \\
\hline 80640 & 60874 \\
\hline 80863 & 60981 \\
\hline 80868 & 60988 \\
\hline 80642 & 609110 \\
\hline 809101 & 60992 \\
\hline 80988 & 60972 \\
\hline 80993 & 60999 \\
\hline 80874 & 609111 \\
\hline 80985 & 609109 \\
\hline 80756 & 60986 \\
\hline 10 & 10 \\
\hline Rerata & Rerata \\
\hline Hasil perolehan data dilapangan & Hasil pengamatan untuk rerata lama \\
\hline menunjukkan bahwa rerata frekuensi flehmen & waktu yang dibutuhkan sapi pejantan \\
\hline dari pejantan Limousin maupun Simmental & Limousin dan Simmental untuk menaiki teaser \\
\hline adalah satu (1) kali.Kecilnya angka perolehan & tertera pada Tabel 4.Data diatas menunjukkan \\
\hline untuk rerata frekuensi flehmen (satu kali) & sapi Limousin membutuhkan waktu menaiki \\
\hline adalah merupakan sebab akibat dari kecilnya & lebih singkat dibandingkan sapi Simmental. \\
\hline angka perolehan & Sapi Limousin membutuhkan lama waktu \\
\hline flehmen.Herdis(2010).Kecilnya & 214,37 detik untuk menaiki sejak digabung \\
\hline perolehan untuk Flehmen dan frekuensi & dengan teaser, sedangkan sapi Simmental \\
\hline flehmen dalam penelitian ini diduga & sebesar $\quad 302,45 \quad$ detik. \\
\hline dipengaruhi oleh jenis kelamin teaser yang & menunjukkan sapi pejantan Limousin \\
\hline digunakan. Sapi pejantan akan berespons & membutuhkan waktu lebih cepat 88,08 detik \\
\hline tinggi menampakan flehmen dan berulang & untuk menaiki teaser pertama kali dibanding \\
\hline apabila digabung dengan betina estrusDenvic & dengan sapi pejantan Simmental. Tampilan \\
\hline Le dkk (2015) yang mengeluarkan cairan dan & menaiki dari kedua jenis sapi pejantan ini \\
\hline bau feromon. Pendapat ini didukung oleh & menggambarkan aktivtas seksual yang \\
\hline Sankar et al (2004) yang melaporkan bahwa & normal.Respons pejantan berupa tingkah laku \\
\hline cairan dan bau feromon yang ada pada betina & sebelum melakukan aktivitas kawin dapat \\
\hline estrus akan mempengaruhi pejantan untuk & dijadikan sebagai \\
\hline menampakkan dan pengulangaı & keinginan kawin (libido) seekor pejantan. \\
\hline
\end{tabular}

\section{Waktu Pertama Menaiki Teaser}

Tabel 4. Lama waktu yang dibutuhkan sapi pejantan Limousin dan Simemental untuk pertama kali menaiki teaser

\begin{tabular}{l|c|c|c}
\hline Bangsa sapi & Rerata (detik) & Sd & KK (\%) \\
\hline Limousin & 214,37 & 201,40 & 93 \\
\hline Simmental & 302,45 & 280,02 & 92,58 \\
\hline
\end{tabular}


Tingginya libido sapi pejantan disebabkan selain karena faktor gen, juga karena manajemen pemeliharaan yang baik.Toelihere (1999) menyatakan faktorfaktor yang mempengaruhi libido dapat berasal dari luar atau dari dalam tubuh ternak tersebut.Kemampuan menaiki (mounting) sapi pejantan dipengaruhi oleh faktor umur.Semakin tua umur pejantan berakibat semakin tidak befungsinya anggota gerak yang disebabkan oleh dislokasi/fraktur (retak) dan osteoarthritis kaki belakang atau tulang belakang.

Manajemen penampungan semen di Balai Inseminasi Buatan Lembang menerapkan false mounting atau pengekangan pada pejantan, dimana saat sapi pejantan menaiki teaser untuk menunda saat ejakulasi.Hal demikian diulang sebanyak tiga kali yang berarti setiap pejantan mengalami tiga kali menaiki sebelum semennya ditampung.Pengekangan dilaksanakan dengan tujuan untuk meningkatkan libido dan untuk menghasilkan kualitas dan kuantitas semen yang lebih baik.Semakin tinggi jumlah false mounting diharapkan semakin baik kualitas spermatozoa yang dihasilkan. Efi (2008) melaporkan bahwa terdapat hubungan yang significant antara jumlah false mounting dengan total spermatozoa semen sapi pejantan MaduraZeidan dkk (1998). Variasi total spermatozoa pejantan sapi Madura 20.205\% dipengaruhi oleh jumlah false mounting.

Upaya lain yang dilakukan oleh pihak BIB Lembang untuk meningkatkan libido pejantan disaat penampungan semen yaitu mengganti teaser, melakukan penampungan di lokasi lain (tidak dikandang kawin), exercise dan menghadirkan pejantan lain yang dianggap saingan. Dari segi manajemen pemberian pakan, pihak BIB Lembang memberikan makanan tambahan berupa tauge yang memiliki protein $29 \%$, asam amino yang lengkap, kandungan vitamin $\mathrm{E}$ dengan tujuan meningkatkan libido pejantan. Toelihere (1999) menyatakan tingginya libido seekor pejantan dipengaruhi oleh faktor genetis dan manajemen pemeliharaan yang baik (pemberian pakan).

Faktor lain yang dianggap penting dalam menunjang aktvitas seksual pejantan yaitu suhu lingkungan. Pengaruh suhu dan lingkungan yang panas dapat mengakibatkan adanya perubahan kelakuan kelamin.Pengaruh suhu dan kelembaban yang tinggi menyebabkan suhu tubuh meningkat dan menurunkan konsumsi pakan serta depresi pada aktivitas reproduksinya (Williamson dan Payne, 1993).Suhu harian di lokasi penelitian mencapai rata-rata $19^{\circ} \mathrm{C}$ (Lampiran 10 ). Hasil pengamatan dilapangan menunjukkan bahwa BIB Lembang dengan suhu $19,3^{\circ} \mathrm{C}$ belum memberikan respon negatif pada pejantan Limousin dan Simmental.Kehidupan dan aktivitas reproduksi sapi pejantan Limousin dan Simmental yang dimanifestasikan dengan tingkah laku seksual prakopulatorik dan pola kopulasi berjalan dengan normal. Iskandar (2011) menyatakan suhu lingkungan dengan kisaran $10-26^{0} \mathrm{C}$ dengan kelembaban $95 \%$ akan memberikan pengaruh performans reproduksi yang baik bagi sapi peranakan Ongole. 
Hasil uji-t untuk lama waktu yang dibutuhkan sapi pejantan Limousin untuk pertama kali menaiki teaser memberikan pengaruh yang sangat nyata $(\mathrm{P}<0,01)$ dibanding dengan sapi pejantan Simmental. Hasil ini menunjukkan bahwa lama waktu yang dibutuhkan untuk pertama kali menaiki teaser sapi pejantan Limousin lebih singkat dibanding sapi pejantan Simmental.Hal ini dapat diartikan bahwa respons atau keinginan kawin (libido) sapi pejantan Limousin yang dimanifestasikan dengan tingkah laku menaiki lebih cepat dibanding sapi Simmental.

Angka capaian untuk lama waktu yang dibutuhkan sapi pejantan Limousin dan Simmental yang ada di BIB Lembang untuk menaiki teaser pertama kali masing-masing $(214,37$ detik $=3,57$ menit $)$ dan $(302,45$ detik $=5,04)$. Angka yang dicapai ini masih dibawah angkapatokan (5-10 menit) untuk melakukan test libido. Tingkat libido seekor pejantan dapat diuji dengan metode "One Bull Methode".Dalam metode ini sapi pejantan diberi waktu 5-10 menit untuk melakukan mounting (menaiki) paling tidak sekali.Kalau sapi pejantan tidak melakukan mounting dianggap gagal (Anonim, 2004).Hal ini berarti bahwa sapi pejantan eksotik Limousin dan Simmental koleksi BIB Lembang selain mempunyai keinginan kawin yang tinggi juga memiliki tingkat fertiitas yang baik, walaupun teaser yang digunakan berjenis kelamin jantan.Feradis (2010b) menyatakan bahwa kemampuan untuk menaiki atau mounting dari pejantan dapat menggambarkan tingkat fertilitas dari pejantan tersebut. Selanjutnya Abror (2010) menyatakan bahwa bull bangsa sapi Eropa adalah bull bangsa sapi yang lebih aktif menaiki pejantan lainnya (Abror, 2010).

\section{KESIMPULAN}

Berdasarkan hasil penelitian terhadap tingkah laku seksual maka dapat disimpulkan bahwa sapi pejantan Limousin membutuhkan lama waktu lebih singkat (2,22 detik) untuk mulai bercumbu dan sapi Simmental $(2,77$ detik), mulai flehmen (222 detik) untuk sapi pejantan Limousin dan sapi Simmental (239 detik) , dan untuk lama waktu yang dibutuhkan untuk pertama kali menaiki teaser (213,87 detik) untuk sapi Limousin dan sapi Simmental $(302,02)$ detik. Sedangkan untuk frekuensi flehmen sapi pejantan Limousin dan Simmental sama(satu kali).

\section{DAFTAR PUSTAKA}

Abror. 2010. Hewan Untuk Agama, Bangsa Dan Masyarakat Semua Jenjang Kehidupan Untuk Mendapat Keridhoannya : BSE, Koleksi Semen. Pemilihan Bull, Dan Hormone Dalam ProsesreProduksi.https://imamabror.wor dpress.com

Anonim. 2004. Diktat : FisiologiReproduksi Ternak. Bagian Reproduksi Dan Kebidanan FKH, Universitas Gajah Mada.Yogyakarta.

Denvic L., L.O. Gerand, E. Sellem, C. Ponsart, P. Chemineuu, P. Humblot, L. Nagnan And P. Meilour. 2015. Enchancing Bull Sexual Behavior Using Estrus Specific Molecules Indetified In Cow Urin. J. Theriogenology 83: 1381-1388

Efi, R. 2008. Hubungan Antara Jumlah FalseMounting Dengan Produksi Semen pejantan sapi Madura. Jurnal Cendekia. Ed Maret:37-43.

Campbell NA; JB.Reece ; And LG.Mitchell 2004. Biologi.Ed 5 Jilid III. Penerbit Erlangga, Jakarta 
Feradis. 2010B. Reproduksi Ternak. Alfabeta, Bandung

Hafez, ESE. 2002. Reproduction in Farm Animals. $6^{\text {th }}$ Ed.Lea And Febiger. Philadelphia

Herdis.2010. Aplikasi Teknologi Laserpunktur Dalam Meningkatkan Libido Pejantan Domba Garut (Ovis Aies).Jurnal Sains Dan Teknologi Indonesia. 12 (1)25-30

Iskandar.2011. Performans Sapi PO Pada Dataran Rendah Dan Tinggi Di Propinsi Jambi.J Ilmu-ilmu Peternakan. 14 (1)35-40

Toelihere., T.L. Yusuf, B. Purwantara dan P. Situmorang. 2003. Karakteristik Penampilan Reproduksi Pejantan Domba Garut. J. Ilmu Ternak dan Veteriner Puslitbang Peternakan Balitbang Pertanian. 65 (1) 134-140.

Sankar, R. and G. Archunan. (2004). Flehmen Response In Bull : Roll Of Vaginal
Mucus And Other Body Fluids Of Bovine Special Reference To Estrus. J. Of Vetenary Science And Technology. 67 (1) $81-86$

Wodzicka T.M., I.K Sutama ,I.G Putu dan T.O Chaniago. 1991. Reproduksi, Tingkah Laku, dan Produksi Ternak di Indonesia. Gramdeia Pustaka Utama. Jakarta.

Yamin M, I.Rahayu, R.Afnan 2014. Tingkah Laku dan Kesejahteraan Ternak ( Pengamatan Tingkah Laku). IPB Press, Bogor.

Lopez, H. A. Onihuela and E. Silva. 1999. Effect Of The Presence Of A Dominant Bull On Performance Of Two Age Group Bulls In Libido Test. Applied Animal Behavior Science. 65. : 13-20

Zeidan, A.E.B., El-Kariem, and Gaafary, M.N., 1998. Effect of Exhaustive Ejaculation on Libido and Semen Characteristics of Friesian Bulls Under Egyptian Condition. Indian Vet. J. 75. : 1011-1013 